\title{
THE ECONOMIC THEORY OF WAGE REGULATION
}

\author{
PaUt H. Douglas*
}

$\mathrm{B}$

ROADLY speaking, the fixation of wages by the state has been advocated for four major reasons: (I) as a means of establishing a minimum below which the pressure of competition and of employers should not force labor; (2) as a means of raising the efficiency of labor and of industry; (3) as a part of a general system of compulsory arbitration with a primary view to preventing or reducing strikes; (4) as a means of building up consumers purchasing power and, therefore, presumably increasing the quantity of goods produced and consumed, as well as the numbers employed.

The first position has been best stated by Sidney and Beatrice Webb and their followers. ${ }^{x}$ Business, it is urged, is characterized by keen competition in the matter of selling price. The businessmen who can undersell their competitors increase their sales volume at the expense of their rivals, and ultimately drive them out of business unless these others follow their example. There is, therefore, a great pressure to reduce costs in order to lower prices; and one of the most effective ways of doing this is to cut labor costs. This can be done by speeding up the output per man hour and by reducing the wage per hour. Even though only a relatively few firms start this practice and cut wages below what is regarded as a decent or an irreducible minimum, this will give them a competitive advantage over their more scrupulous fellows, which if continued will enable the "meaner" men to capture the market. The more conscientious employers, in order to survive, are then reluctantly forced to cut wages down to the level fixed by the less scrupulous. And when this is done, the latter tend to initiate a fresh series of wage reductions, which in turn must be followed. In this way, the meanest men set the terms of competition under which the struggle for survival takes place; and the result is a progressive deterioration of the standard of life of the working classes.

The Webbs traced this pressure back to the desire of consumers for cheaper goods. The retailers whose articles were higher priced than their competitors would lose trade, and hence would put pressure on the whole-

* Professor of Economics, University of Chicago.

×. and B. Webb, Industrial Democracy 654-702 (r920 ed.). 
salers for lower prices, who in turn would push the manufacturers to reduce their prices. These would take it out of the workers because of the weaker bargaining position of the latter. "We thus arrive at the consumer," declared the Webbs, "as the ultimate source of that persistent pressure on sellers, which, transmitted through the long chain of bargainings, finally crushes the isolated workman at the base of the pyramid."

The individual workers are unable to stand out against this pressure for lower wages because of certain inferiorities in bargaining power. First, there is presumed to be an appreciable amount of unemployment in all the phases of the business cycle, with the possible exception of the boom period. The workers will, therefore, accept a low wage in order to avoid the alternative of unemployment, when they would earn nothing. The employers can, therefore, use the presence of unemployment as a means of playing off the workers against each other, and hence forcing down the wage scale. Second, even if a worker is ultimately to be employed, the loss of the intervening period of work is generally far more important to him in view of his limited resources than is the loss of his services to the employer. This puts him at a disadvantage in negotiating the terms upon which he is to work. Finally, the worker has less knowledge of how high a wage the employer is willing to pay than the employer has of the lowest wage which the worker is willing to accept. This is of great advantage to the employer in striking the wage bargain as it is to any purchaser.

That such competition can lead to a great reduction in wages and to a deterioration of labor conditions in general has been evidenced by a number of examples. Among these are the fall in wage rates in the American coal mining industry during the nineties, when by 1897 the average yearly earnings had fallen to $\$ 270$, or $\$ 5.40$ for a week, and to an hourly rate of about I 3 cents; ${ }^{3}$ the sweated condition of the men's and women's clothing industry during the quarter-century from 1890 to I9I4; the low wages which have been and are being paid in such industries as the making of candy, the shelling and packing of nuts, the manufacture of cotton garments and work clothes, the manufacture of textiles in certain regionsparticularly in the south, the cutting and sawing of southern timber, and a large number of other instances, which indicate that the condition is actual and not merely theoretical.

The two remedies proposed to check this tendency, are first, unionism and collective bargaining, and second, legal enactment. Both aim to set a

3 Id. at $67 \mathrm{I}$.

${ }^{3}$ See P. H. Douglas, Real Wages in the United States I890-I926 I52, 350 (I930). This makes an allowance for unemployment. 
minimum of wages and working conditions below which the pressure of competition cannot force the workers. In the words of the Webbs, these serve as dikes to protect the worker from the nibbling at the rate; while in the language of the late Professor Henry C. Adams, they set the plane upon which competition operates. Under this philosophy, the question as to which of these two methods is to be used depends largely upon the circumstances of the case. Where effective unionism is characteristic of an industry or can be extended over it, then there is a general presumption, so far as thesê considerations are concerned, to allow the voluntary organization to cope with the matter. Where collective bargaining is introduced on such a wide scale, the minimum time and piece rates, the length of the normal working week, and the basic working conditions can be set through the collective agreements. Where, however, it is virtually impossible to establish collective agreements, or where unionism is only able to establish itself in a minority of the units in an industry and is constantly menaced by the under-cutting of the non-union firms, then it is urged that action by the state is necessary, since the latter alone will have the power of effective compulsion. In numerous countries, therefore, the state has tended to single out numerous groups of workers which it regarded as not being sufficiently able adequately to look out for themselves, and who hence needed special protection. Thus, the state of Victoria in Australia established trades boards in the I89o's to protect those in badly sweated industries who seemed unable to organize and who lacked mobility, ${ }^{4}$ and this practice was copied by Tasmania, and in I9II by Great Britain when it passed its Trades Board Act. ${ }^{5}$ It was also adopted in I9I 5 by France for home-workers; ${ }^{6}$ and has been followed for women by a considerable number of the states in this country, ${ }^{7}$ and by most of the Canadian provinces. ${ }^{8}$

4 See Collier, Wage Legislation in Australasia, Fourth Annual Report in New York State Factory Investigation Commission, Vol. IV, pp. 185I-2268 (Igr5).

5 Burns, Wages and the State 89-IO2 (Ig26); Sells, The British Trade Boards System (I923); Report to the Ministry of Labour of Committee into the Working and Effects of the Trade Board Acts (Cave Committee) Cmd x645 (I922); Minutes of Evidence before the Cave Committee ro5o (1922).

${ }^{6}$ Burns, The French Minimum Wage Act of r9r 5, 30 Economica, pp. 236-44 (r923).

7D. W. Douglas, American Minimum Wage Laws at Work, 9 American Economic Review 70I-38 (I9I9); Andrews, Minimum Wage Legislation, Appendix III, New York State Factory Investigating Commission (1914); Clark, Minimum-Wage Laws of the United States: Construction and Operation, Bull. 285, U.S. Bureau of Labor Statistics (1921); The Development of Minimum-Wage Laws in the United States I9I2 to I927, Bull. 6I of Women's Bureau, U.S. Department of Labor (1928); Frankfurter, Dewson and Commons, State Minimum Wage Laws in Practice (I924); Operation of Minimum Wage Laws, Consumers League of Ohio and Ohio Council of Women in Industry (rg24).

${ }^{8} \mathrm{~K}$. Derry and P. H. Douglas, The Minimum Wage in Canada, 30 Journal of Political Economy I55-88 (1922). 
II

The second main argument in favor of government regulation of wages is that by raising the wages of the lower paid, the economic efficiency both of the workers and of industry itself would be raised. This contention has, in turn, a number of strands. Higher wages to the underpaid would enable them to obtain better food, more adequate clothing, etc., and hence would build up their strength so that they ultimately could and would do more work. The increased wage would be a good investment for industry as a whole, although individual employers in the past had not thought so because there was no surety they could retain the services of those whose wages they might increase, and because they felt confident of replacing those of their workers whom they enfeebled by others drawn from the common pool.

Secondly, higher wages would tend to lead to the introduction of more effective methods of management. Slovenly management, it is contended, is encouraged by the practice of paying low wages, since firms find it possible to survive by "sweating" their employees. The raising of wages to a more decent level would, it is argued, remove this possibility and would force many firms to improve their efficiency and conduct of the business or go under. This stimulus would force many inherently competent but erstwhile inefficient firms to arrange their flow of materials better, to reduce wastes and to improve their marketing methods.

Again, higher wages would lead to the introduction of more machinery, and hence to an ultimate reduction in costs. If labor is cheap, it frequently will not pay to use much machinery, but every increase in wages will increase the possibility of substituting machinery for labor, and hence will operate as a deterrent to prevent unit costs of production from increasing by as much as hourly wage rates. The investigations of Ernest Aves into the workings of compulsory wage regulation in Australasia, ${ }^{8_{a}}$ and by the Cave Committee and by Miss Sells into the operation of the British Trade Boards Acts, ${ }^{9}$ furnishes inductive corroboration that these results have occurred in some degree where wages have been raised as a result of government rulings.

It is true that if wages are raised, not in a few industries, but universally and by approximately equal amounts, the incentive to use machinery will be reduced, since the costs of the machinery will also be raised by reason

8s Ernest Aves, Report on the Wages Boards and Industrial Conciliation and Arbitration Acts of Australia and New Zealand, 7 I Great Britain Parliamentary Papers (Igo8).

9 Sells, op. cit. supra note 4, 224-42; see the excerpts of testimony before the Cave Committee in I Frankfurter and Dewson, Brief for Appellants in Adkins v. Children's Hospital $3^{\text {I }} 4^{-24}$ (I922). 
of the wage increases in the capital producing industries. ${ }^{10}$ But since interest on capital forms a part of the cost of these machines, their cost will tend not to be increased by as much as the costs in the industries producing consumers goods, and there will tend to be some substitution. This will be even more the case if the increases are confined to the consumers goods industries, or are greater there than in the capital goods industries.

But it is here that the practical man of affairs will interpose the objection that this process of substitution will necessarily throw some of the former workers out of employment, and hence be of doubtful benefit from the standpoint of the workers themselves. It is true that if all other things are equal, there will be some such tendency in the immediate industries concerned. But it should also be remembered that any such tendency will be mitigated, and the unemployed probably ultimately absorbed into employment by the following factors: $(a)$ There will be an increased demand for and an increased production of machinery and durable capital goods. This will require more workers, and these can be found either by transferring directly some of the displaced employees or, as is more likely, by a series of intermediate shiftings of jobs which will serve to absorb at least a respectable fraction of the originally unemployed. (b) The increase in the quantity of capital goods used will result in a larger total sum being received by the capitalistic or investing class. For while the interest rate may be lowered slightly by the increase in the quantity of capital, ${ }^{\text {Ix }}$ this reduction will not be proportionately as great as the increase in the quantity of capital upon which interest is paid. ${ }^{\mathrm{i}}$ This increased income of the capitalists will not be permanently held idle, but will sooner or later be de-

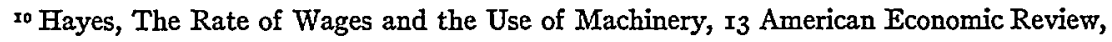
$46 \mathrm{r}-65(\mathrm{rg} 23)$.

Ir According to the principle of diminishing incremental productivity, which will be explained later.

sz Because the flexibility of the marginal productivity curve (i.e., the curve of diminishing increment) seems definitely to be less than what the economists term unity, namely, that if $\mathrm{C}=$ total original quantity of capital, and $\Delta \mathrm{C}$ the increase in this quantity; and if $\mathrm{P}=$ total original product, and $\Delta \mathrm{P}$ the increase in this: Then marginal productivity, or M.P.C $=\frac{\Delta \mathrm{P}}{\Delta \mathrm{C}} \cdot \phi \mathrm{C}$, is the flexibility of the marginal productivity curve; or the relation which proportionate changes in the marginal productivity bear to given proportionate changes in the quantity of capital, is then, $\frac{\Delta . M . P . C}{\text { M.P.C }} / \frac{\Delta C}{C}$ and from inductive studies by the author and his associates, the numerator $\frac{\Delta . M . P . C}{\text { M.P.C }}$ is almost certainly less than $\frac{\Delta C}{C}$. See P. H. Douglas, The Theory of Wages $x$ I $^{-227}$ (I934); P. H. Douglas and Handsaker, The Theory of Marginal Productivity as Tested by Data for Manufacturing in Victoria, 5r Quarterly Journal of Economics $1-36$ (I937), and a concluding installment in February, 1938. 
voted to one or both of the following purposes, namely, spent on articles or services for personal consumption or invested in industry. In either event, it will increase the demand for labor, and hence promote the ultimate $a b-$ sorption of those originally displaced. (c) Since these processes of absorption will take time to work out, the case is strong for a system of unemployment insurance which will at least partially compensate the displaced workers for the loss of earnings which they suffer prior to reemployment.

(d) Finally, even if the increase in wages is not sufficiently compensated for by the three preceding types of economizing so that some firms who were close to the margin are in fact forced out, the displaced workers will be in whole or in part absorbed by being taken into the employment of the more efficient firms which can still flourish, and which may indeed have been already meeting or exceeding the wage fixed by the government body. In these firms, the average physical and value output per worker will be greater than in the original concerns, so that the net social productivity of industry will be raised by the transfer of labor.

The question as to whether the more efficient firms will take on as many workers as those who lost their jobs in the relatively inefficient plants will depend on a number of factors, of which the chief is whether the demand for the article is such that a slight fall in price is accompanied by a greater or less proportionate increase in quantity demanded, is perhaps the most important. In the former case, the workers can in all probability find permanent employment in the other firms within the same industry. In the latter case, there will be some displacement within the industry, but the released purchasing power of the ultimate consumers ${ }^{13}$ will create employment opportunities elsewhere.

III

A third set of forces leading to the state fixation of wages is the desire to reduce the number of strikes and lockouts by establishing compulsory arbitration. Such trials of strength between unions and employers involve an interruption of production which at times hampers the consuming public. They are frequently accompanied in some countries by violence on the part of pickets, strike breakers, and the police, which turn the strike into a form of miniature class and civil war. Under these circumstances, the consuming public as represented by the salaried, middle, and farming classes are likely to demand compulsory arbitration as a substitute for the strike

${ }^{13}$ In this case, they will be spending a smaller total quantity upon the article in question, and hence will have more to spend elsewhere. See an article by the author, Technological Unemployment, (30) American Federationist, pp. 923-50 (1930). 
and lockout. Trial by combat, it is argued, has long since been abandoned in other acute conflicts of interest, and these are instead submitted to the arbitrament of the law. There is no surety that a just agreement will emerge from such clashes for the results will be determined by the relative strength of the two contestants rather than by the comparative justice of their claims. In addition, the struggle itself seems to many wasteful and unnecessary. How much better, it is argued, for these disputes to be submitted to an impartial tribunal which would then render its decisions according to the canons of justice, and which would bar any recourse to a trial of economic strength. ${ }^{\mathrm{I}}$

Such considerations make a powerful appeal in periods of labor disturbance not only to consumers who are not immediately involved in the conflict, but also to legally-minded persons who like to think of freedom as "slowly broadening down from precedent to precedent." It is reinforced, however, by shrewd calculations by employers and the manual workers respectively of the relation between their political strength and their economic power. If the workers feel weak economically but strong politically, and see no real prospect of a change in their position, then they will tend to favor compulsory arbitration, as they did in New Zealand in the I89o's after they had lost the disastrous maritime strike, ${ }^{\mathrm{IS}}$ and which operated also in Australia. For then, by controlling or partially controlling the state, they believe they can get better terms than through voluntary agreements. ${ }^{16}$ On the other hand, if they feel stronger economically than politically, or if they are fearful of losing political strength in the future, they tend to oppose compulsory arbitration, and instead, to favor collective bargaining.

Similar considerations determine the attitude of the employers. If they

${ }^{34}$ Such, it may be surmised, were the sentiments affecting Richard Seddons and W. Pember Reeves, the leaders of the New Zealand Liberal Party, which first passed compulsory arbitration in I894. It was probably also a force affecting Governor Allen, W. L. Huggins and others, who passed the Kansas act of I920. See Allen, The Party of the Third Part (I921); Huggins, Labor and Democracy (I922); Bowers, The Kansas Court of Industrial Relations (I922); Feis, The Kansas Court of Industrial Relations, 37 Quarterly Journal of Economics 705-33 (I923).

rs See Reeves, The Long White Cloud 289 ff. (I924); 2 Reeves, State Experiments in Australia and New Zealand (rgo2).

${ }^{36}$ The recent situation in France, where labor supported a compulsory arbitration law which was passed in December, I $_{93} 6$ (see 6I Industrial and Labor Information, International Labour Office ${ }^{232-} 35$ (Feb. 22, I937), is somewhat more complicated. Labor had won, eight months before, a political victory in returning the Popular Front coalition to power, and it had also won a series of strikes which had sent its union membership up from about one and a quarter million to five million members. But it was fearful lest further strikes would drive the middle classes towards fascism; and it had confidence in its ability to wield political influence. 
have great economic strength, but have either lost or are fearful that they may lose control over the state, they will be opposed to governmental intervention. If, however, the unions are too powerful for them on the industrial field or cause them great losses, but the employers are confident that they can control the government, then the latter will want to forbid strikes and establish arbitration machinery which will more or less do their bidding. Illustrations of the latter tendency are seen in the prohibition of strikes with the attendant machinery for "settling" industrial disputes in fascist Italy. ${ }^{17}$

Sometimes there is a mixture of many of these forces, as in Australia, ${ }^{18}$ which leads to the adoption of compulsory arbitration.

Once compulsory arbitration is established, then the government tribunals are forced to set wages in the cases which come before them. In fact, they are soon forced to give a rather general application to those rulings which they make in specific cases. For if a tribunal were only to increase wages in a specific plant where a dispute broke out, then it would handicap that plant in its struggle for survival. Conversely, if decreases were granted to one firm alone, it would be favored. In order to preserve competitive equality, the arbitration body is therefore forced to extend its rulings to at least the major portion of the firm's competitors as well. Disputes which might otherwise be more or less confined to one plant or section of an industry serve, therefore, to pave the way for decisions affecting the industry as a whole.

Where the tribunal is at least mildly favorable to labor, the rulings tend to be broadened in a second manner. The workers know that they will not be forced to strike in order to raise an issue, since the arbitration machinery exists to prevent just such a step. They, therefore, can ask for increases and improvements in plants where their degree of organization is weak, since they have nothing to lose by such action. The arbitration body will, therefore, speedily be plunged into the general fixation of wages. ${ }^{\text {I9 }}$

\section{IV}

The final main argument for the state regulation of wages is the socalled "purchasing power" theory. The consumers of the predominant

${ }^{17}$ Rosenstock-Franck, L'Economie corporative fasciste en doctrine et en fait (I934); Salvemini, Under the Axe of Fascism (1936); Finer, Mussolini's Italy (1935).

${ }^{18}$ Anderson, The Fixation of Wages in Australia (1929); Higgins, A New Province for Law and Order (1922); Clark, The Labour Movement in Australasia (r9o6); O. R. de Foenander, Towards Industrial Peace in Australia (1937).

19 See Le Rossignol and Stewart, State Socialism in New Zealand 216-49; (rgro) Broadhead, State Regulation of Labour and Labour Disputes in New Zealand (rgo8). 
proportion of mass production goods and services are the industrial wageearners, the lower-paid clerical and professional workers, and the farmers. Many modern theorists, like Malthus, ${ }^{20}$ Sismondi, ${ }^{21}$ and Owen ${ }^{22}$ a century ago, believe there is a tendency for the sum total of monetary purchasing power in the pockets of the consumers of these goods to be less than the sum total of the price tags on these goods. When this happens, it is argued, there is a greater quantity of goods produced than will be demanded at the given price level; and the result will be that business will close down part of its capacity in order to work off its unsold accumulation of stock. But this will destroy purchasing power and lead to fewer purchases, with all the cumulative chain of consequences which hung society into a deeper economic depression. ${ }^{22 a}$

The ultimate cause of the breakdown is believed by this group to be an insufficiency in the quantity of consumers purchasing power to buy the quantity of goods produced at the prices charged. There is no unanimity, however, within this group as to the reasons why this insufficiency should exist. Some, like Major C. H. Douglas, ${ }^{23}$ believe it is due to the nature of our system of banking and credit. Others ascribe the primary causes to monopoly. ${ }^{24}$ While still others, following Marx, think the real roots are to be found within the capitalistic system itself and in the extraction of "surplus value."

Many, nevertheless, accept this theory in its general outlines without troubling to analyze deeply the fundamental reasons why they believe it. Whereas the followers of Major Douglas believe in the socialization of credit as the cure for the disparity; the anti-monopolists in a forced return to competition which will reduce prices, and hence enable all the commodities to be bought; and the Marxians in a social order where wages will be virtually the sole distributive share, this larger body holds that what is needed is an increase in wages and the lower salaries, so that the purchasing power of the consumers will be built up to the productive capacities of industry. In so doing, they believe sufficient customers will be provided for industry so that if a country is in a boom period, unsold inventories

${ }^{20}$ Malthus, Principles of Political Economy (1820).

"s Sismondi, Nouveaux principes d'économie politique (1827).

23 Owen, A New View of Society (1818); Report to the County of New Lanark (1821).

${ }^{22 a}$ For a description of the cumulative nature of this process, see my Controlling Depressions, pp. 9-3x (I935).

${ }_{23}$ C. H. Douglas, Social Credit (1933); Soddy, Wealth, Virtual Wealth and Debt (1933); Soddy, Money versus Man (r933).

${ }^{24}$ P. H. Douglas, Controlling Depressions (r935). 
will not be accumulated and a crash will consequently be averted. If a depression is under way, it is believed that the increase in the purchasing power of the workers will restore prosperity. The advocates of this theory realize that individual industries cannot do this by themselves, since a worker spends but a very small fraction of his income upon the product which he helps to turn out. An increase in wages by one firm, and even by one industry, therefore, increases the costs for that particular enterprise or brand of trade, but does not increase to any appreciable degree the total demand for its product. Such a policy may aid other industries, but it does not aid the innovating group. If improvement is to be effected, therefore, it is necessary that all industry should be forced simultaneously to increase wages, and hence reciprocally provide increased demand for one anothers' products. Only the government can do this, and state regulation of wages comes to be regarded as a business necessity. Such, in brief, was the economic theory which lay behind the N.R.A. in this country.25 The reply of the hard-headed orthodox economist to such arguments is that an increase in wages obviously increases costs by the same absolute amount as it increases monetary consuming power and, therefore, there is no net increase in real purchasing power. The increase in costs and prices, it is said, cancels the increase in the money incomes of the workers; and to attempt to raise general purchasing power by raising wages is equivalent to a man trying to lift himself by tugging at his own bootstraps. Furthermore, it is asked, from whence is the increase in monetary purchasing expected to come? The ultimate sources under our present system are the privately owned banks; but the mere fact that the costs of business have increased does not ensure that the banks will so increase their loans to business as to enable the higher total sum of wages to be paid.

These objections are weighty. If, however, more monetary purchasing power can be squeezed out of the banking system through the creation of more credit, or if idle corporate reserves can be drawn upon, then it is possible for an increase in wage payments to increase total demand and output; but only under the following conditions:

I. If the increase in money payments is largely spent upon goods and services which, produced under past conditions of lower wages and costs, are not marked up to the full extent of the rise in current wage rates.

2. If this leads to an increase in the quantities of goods ordered by retailers, wholesalers, etc., and hence in the quantities turned out by such basic industries as manufacturing, etc.

${ }^{25}$ See Lyon, Homan, Terbogh, et al., The National Recovery Administration (1935). 
3. If overhead costs are reduced by this increase of output. This largely depends on the price policies of industry. If there has been a practice of loading fairly heavy overhead charges upon the reduced output which a depression brings, then an expansion in output might well permit these charges to be reduced per unit. This in turn would help to counterbalance the increase in labor costs so that prices need not rise subsequently by as great a ratio as wages, and consequently a continuing increase in real purchasing power would be obtained.

Phrased in this fashion, the purchasing power argument contains more sense than its opponents have been willing to admit. But it must be recognized that for it to be realized, virtually all of the above conditions must be met; and if they are not, the method largely ceases to have value and may, as we shall see, do positive harm.

\section{$\mathrm{V}$}

The scope and degree of the wage regulation which is carried out by the state depends, as I have hinted, upon the relative strength of the sets of purposes which have been briefly analyzed. If the purchasing power theory is dominant, then an almost universal degree of regulation follows almost inevitably. For since the purpose is to increase the total purchasing power, and this is presumed to be done by an increase in money wage rates, then obviously it is only logical to sweep as many groups as possible into the system.

The effect of the system of compulsory arbitration depends upon whether it is confined by law to a few vital industries, such as railroads, etc., where an interruption is thought to be particularly dangerous; or whether it is intended as a reserve method for settling disputes in society as a whole. In the latter case, state regulation of wages for the reasons already stated tends to become widespread and to be in fact the predominant method of wage adjustment.

If those who wish to use state regulation as a means of raising the plane of competition are primarily middle class reformers, then this method is likely to be restricted to the most sweated industries or classes; while for the major part of the economy, wages will be fixed by individual bargaining or collective agreement. Finally, in countries where the individualistic philosophy is strong, and where men are presumed to be able to take care of themselves, there is a pronounced tendency to confine the legislation to women and minors, but not to extend it to men. This is the present situation in the United States and most of Canada, in contrast with that of Great Britain and Australasia, where men are also included. 
VI

STANDARDS FOLLOWED IN FIXING BASIC WAGES

A wide variety of principles are admitted into the fixation of the basic wage. In some cases, as in the case of the fixation of basic wages for men and women in New South Wales and the other Australian states except Victoria, in the decisions of the Australian Commonwealth Court of Arbitration, and in most of the early minimum wage statutes for women of the American states, the basic standard is presumed to be that of the "living wage." In other cases, such as the trade boards in Victoria and Great Britain, no explicit standards are laid down, and the administrative tribunals are left more or less free to use whatever criteria they deem best. Sometimes, as in the Massachusetts minimum wage law, the ability of the industry to pay is to be expressly considered and is to constitute a limiting factor upon any wage set. Finally, the obiter dicta of Mr. Justice Sutherland in Adkins v. Children's Hospital ${ }^{26}$ led numerous states which passed subsequent laws to add a second criterion, namely, that wages fixed should not exceed the "fair value of services rendered."

But whatever the explicit rules of judgment are supposed to be, certain considerations are bound to affect the wage-fixing body. If it is moved at all by humanitarian considerations, as will tend to be the case in states with a liberal tradition, it will have to take into consideration the cost of living, however vaguely or inexactly it may define such a concept. But even where this is the only criterion which it is supposed to follow, it will in practice be forced to consider also the state of business both generally and in terms of specific industries, and the probable effects upon prices, profits, and employment of any ruling.

In so far as the minimum cost of living is concerned, the basic assumption is that the vast mass of workers actually produce enough to support and reproduce themselves and that if they are paid less, it is because they are being exploited through the superior bargaining strength of their employers. The fact that society is able to reproduce itself and show a net population growth with an expanding average standard of life is regarded as proof that the workers as a whole are not parasitic and that they produce their keep. Where a specific industry gives to its workers less than enough to "support" them, and enable them to at least reproduce themselves, it is regarded as being parasitic and as taking from the workers strength and energy which it does not restore in the form of an adequate wage. To compel the industry to pay a living wage is, therefore, regarded

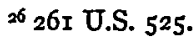


as being merely a measure which compels employers and consumers to restore to those who produce the articles in question at least as much physical energy as has been expended upon their production. ${ }^{27}$

The skeptic will, of course, reply to all this by saying as a defense against general wage regulation: (I) that the very fact of population increase is itself proof that industry as a whole is not parasitic; for if it were, no such growth could result. And if to this, it is objected that it is possible for a luxuriant quantity of second-rate and enfeebled quality to flourish among men as it so frequently does among trees, and yet for qualitative deterioration to occur, the reply of the opponent of wage regulation is that there is little or no evidence that this has been occurring in the western and New World countries. Instead, there has been a prolongation of life and an apparent increase in average bodily well-being.

(2) As a defense against wage regulation in specific substandard industries, the skeptic contends that these attract sub-standard persons who cannot hold their own in the industries where the pace is faster and the need for intelligence greater. These men and women tend instead to gravitate to those industries which will give them shelter, and hence predominate there. What seems to be a parasitic wage is, therefore, said not to be such in fact; but is instead merely that which these inferior persons produce. It is not the industries which are parasitic upon the workers, declare this group, but the workers who are parasitic upon society.

This claim is denied by the advocates of wage regulation, but the question is indeed one which is not susceptible of definite proof prior to the establishment of wage minima. After such standards are put into effect, some indication of the respective validity of the contentions can be observed from whether or not the previous workers are retained at the higher wage, or whether they are discharged. If they are still retained, then there is a presumption that the primary fault was originally not in the workers but in the wage. Even here, however, there is still the possibility that the higher wage will have been paid not out of the efficiency of the workers, but out of higher prices by the public, and hence constitute an indirect subsidy to enable the unfit to live upon a more humane standard of life. This issue may be susceptible of verification, but it also may not be.

Once the idea of a "living wage" or something approaching it is approximated, there remain at least two further questions: (I) What is in fact the content in goods, services, and money of a living wage for an individual?

${ }^{27}$ See S. Webb, The Economic Theory of a Legal Minimum Wage, 20 Journal of Political Economy 973-98 (I9I2); Kelley, Some Ethical Gains through Legislation (I905). 
(2) How many individuals are in fact dependent upon a given worker for support, and for how many should an industry assume such an obligation?

The content of family and individual budgets has been studied by a large number of competent authorities, ${ }^{28}$ and in general at least five levels or planes of living have been defined: (I) The poverty scale, upon which a person or family may live for a time, but which is inadequate as a permanent basis because of the lack of provision made for replacements of clothing, furniture, household goods, etc., and which, by providing inadequate medical and dental care, would also make inroads upon health. The crowding to which the family would be subjected might also well impair the morals and good temper of its members. (2) The minimum of physical subsistence scale, which would provide for adequate food, clothing sufficient to ward off the cold, and not quite as bad housing as that obtained by those on the lowest level. Comparatively little would, however, be allowed for amusements and incidentals, and in practice most of the families would prefer to spend some money on these and other items than upon the apparently more "necessary" food items. The result is that in practice the full minimum food quantities are not purchased until the income is somewhat above the figure set for this level. (3) The subsistence-plus level which allows more money for housing, clothing, incidentals, education and medical care. (4) The health and decency level, which is still more liberal. (5) The comfort level, which is roughly similar to what is meant by the term: "American standard of living" and which would allow at least one room per member of the family, two suits of clothes per year for the head of the household, a fairly adequate provision for insurance, brief vacations, occasional trips to the movies, and the use of a secondhand automobile.

The actual physical content of these various planes of living can be approximated with some degree of accuracy. Due allowance should, however, be made for the climate, and in the case of the upper levels, for the social customs of the given region. Then the articles and services can be priced and the cost of maintaining a given level be obtained. These prices can be taken periodically so as to take due account of changes in the cost of living.

\footnotetext{
${ }^{28}$ More, Wage Earners Budgets (rgo7); Chapin, The Standard of Living in New York City (Ig09); Beyer, Workmen's Standard of Living in Philadelphia (rgIg); The Chicago Standard Budget for Dependent Families, Chicago Council of Social Agencies (r929-3I); Standards of Living, Bureau of Applied Economics (Igrg); Studies by the National Industrial Conference Board and the Labor Bureau (rgr8-20); Eliot, American Standards and Planes of Living (193I).
} 
The issue as to how many dependents a worker should be supposed to support has been an even knottier question. Originally, the tendency was to assume that a man would be expected to have a family of five dependent upon him, ${ }^{29}$ while an employed woman would be expected to be living away from home. ${ }^{30}$ The theory behind the "family of five" assumption was twofold: (I) It was thought that five was the average size of family. This was because the average size of the "household" in the United States in I8go was of approximately this number, although the "household," by including all those who kept house together under one roof covered hotels, prisons, and insane asylums, and was necessarily larger than the "family." In I930, incidentally, the average size per household was approximately 4.o. (2) It was thought that each male worker needed a wife and three children to replace him. Two children were obviously needed to take the place of the parents, while another child was said to be necessary to allow for deaths prior to marriage, bachelors and spinsters who never married nor reproduced their kind, and sterile marriages. What this assumption ignored, however, was the fact that a man would not be married throughout his working life, and that he typically would not have three children dependent upon him for the major portion of his working years. For there would be some years after marriage before he had three such children, and after a time, they would grow up and become self-supporting. While the dependency of three children might be a stage through which the typical worker would pass, it was not a permanent characteristic.

As a matter of fact, a simple illustration will show the excess loading which the adoption of a family of five standard would involve. There were in I930, 35,052,000 males of 20 years and over who were gainfully occupied. ${ }^{3 x}$ If each of these were to have been provided with maintenance for five people, the total number thus cared for would have been $I 75,260$,ooo. Assuming that the $2,565,000$ males from I6 to I9 years inclusive, and the I0,546,000 females from I6 years up should under these conditions at least receive enough to maintain themselves, this would give a total of I 88,37 I, 000 persons who would be maintained. But the total population of the country in that year was only $122,775,000$. The universal payment of such a wage or income would provide for approximately $65,600,000$ fictitious and non-existent wives and children.

${ }^{29}$ Rowntree, Poverty (Igor).

${ }^{30}$ Taussig, Minimum Wage for Women, 30 Quarterly Journal of Economics 4I I-42 (Igr6); D. W. Douglas, The Cost of Living for Working Women, 34 Quarterly Journal of Economics 225-59 (I920).

${ }^{31}$ Statistical Abstract for r933, p. 53. 
Since there were in reality only 36.0 million children under 15 years in this country in 1930 , and 47.6 million under 20 years of age, ${ }^{32}$ the average number of children to be supported by the 35 million occupied males of 20 years and over was only 1.03 or at the most 1.36 , instead of the 3.0 which would be assigned to them under the proposed standard.

When these figures are analyzed more closely, the essential absurdity of using the family of five standard for all workers becomes more evident. There were, for example, 9,300,000 males of 20 years and over who were

TABLE $1^{*}$

AMERICAN FAMILIES IN I930 CLASSIFIED ACCORDING TO NUMBER OF CHILDREN UNDER IO AND 21 YEARS, RESPECTIVELY

\begin{tabular}{|c|c|c|}
\hline \multirow{2}{*}{ Number of Children } & \multicolumn{2}{|c|}{$\begin{array}{c}\text { Percentage of Faumites } \\
\text { Having Cerldren }\end{array}$} \\
\hline & $\begin{array}{l}\text { Under ro } \\
\text { Years }\end{array}$ & $\begin{array}{l}\text { Under 2x } \\
\text { Years }\end{array}$ \\
\hline 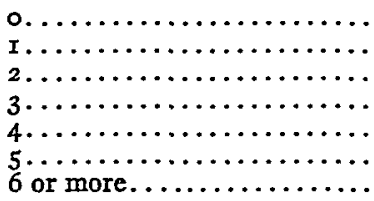 & $\begin{array}{r}58.8 \\
19.2 \\
11.8 \\
6.0 \\
2.8 \\
1.0 \\
0.3\end{array}$ & $\begin{array}{r}38.8 \\
20.8 \\
16.2 \\
10.1 \\
6.1 \\
3.6 \\
4.5\end{array}$ \\
\hline
\end{tabular}

* Fifteenth Census of the United States, Vol. VI, on Population, 8 (r930).

bachelors. It could not, I believe, be seriously maintained that these had families of five to support!

Then, of those who did have families, Table I shows the percentages which had the given number of children under Io and $2 I$ years of age, respectively. This shows that virtually 59 per cent of the families ${ }^{33}$ had no children at all under the age of 10,78 per cent had fewer than two children, and 89.8 or virtually 90 per cent, had less than three such children. Only 6 per cent had exactly three children under the age of Io, while but 4.I per cent had more than three children.

It is, of course, improper to regard only the children under ten years as dependent upon adults, since children should not go to work and become

32 Fifteenth Census of the United States, Vol. II, on Population 38 (r930). This figure, of course, included some who were not gainfully occupied.

33 Between one-eighth or one-ninth of these were single member families of persons living by themselves. This should be borne in mind as a slight qualification to the figures cited above. 
self-supporting until appreciably later. The use of such an age limit therefore very distinctly understates the number of dependent children, and unduly increases the proportion of those listed as having few or no children in this category. If we take twenty-one years, however, as our top age, we will certainly be overstating the number of such dependents, since few will contend that all children should be supported by their parents until they reach the age of twenty-one. Yet even on this basis, there were 39 per cent of the families which had no such children, ${ }^{34}$ and 59.6 per cent which had less than two, and 75.8 per cent with less than three. Only Io per cent had precisely three children under twenty-one years, while 14.2 per cent had more than three such children.

If all male workers were, therefore, paid enough to support a family of five, vast surpluses would be poured into the pockets of the majority. The needs of only a small fraction would be met while a considerable percentage of the workers would not receive enough to support their children. And those children, incidentally, would form a very considerable fraction of the total number of children to be maintained. From rough computations it appears that about 25 per cent of children under ro years of age, and 45 per cent of those under $2 x$ years, belonged to families which had more than three such children. The family of five wage is, therefore, like the bed of Procustes, that mythological inn keeper, who hacked off the legs of his tall guests to fit his sleeping accommodations, and who put his shorter visitors upon the rack in order to stretch them out to the prescribed length.

In the case of women, the assumption that the costs to be met are those of a single woman living away from home has been challenged from both extremes. Some, such as Professor Taussig, have pointed out that most women workers live within the family unit, and have urged that the direct costs for such women rather than those living away from home should be taken as the standard. If, however, the unpaid services of the mother are taken into account, and if an industry is to be charged with some share of this family overhead cost, then the difference between the costs of living for these two classes of women is reduced to a comparatively minor range. This is still further diminished if the women at home are to be given some allowance for saving for matrimony or for some other eventual contingency.

The extreme feminists have, on the other hand, challenged the standard of a single woman living away from home on. the ground that many

- ${ }^{34}$ This is of course subject to the qualification which has been mentioned in the previous footnote. 
women have numerous dependents and that a proper basic wage should make provision for them as well as for the dependents of men. It is, therefore, argued that the basic wage for women should be enough to support a family of five or at least four.

The objections which have just been advanced against the use of such a standard for men apply, however, with even greater force in the case of women. For the percentage of women who have two or more dependents to support is far less than the percentage of men. The exceptions should not be confused with the rule nor made the basis for the treatment of all. To the degree that the dependents are the children of widows, a better method of caring for them would be to provide more adequate mothers' pensions, such as are now being jointly financed under the Social Security Act by the federal government and the states. To the degree that they are the aged mothers of working women, protection can be given either through old age pensions or allowances for aged dependents, such as those which I shall propose for children in the final section of this article.

There would seem, therefore, to be sound ground for retaining the cost of maintenance for a working woman living away from home as the standard in the case of women.

The standards which should be followed in considering the ability of an industry to pay are even more complicated, and may briefly be summarized as follows:

I. If, as often happens, there is a considerable variation in the wages paid by different employers for the same type of labor, and if those paying the higher wages are still able to survive, there is a strong presumption that the minimum scale could be raised to equal that paid by the "better" employers. This need not be the highest wage paid, but it can be in the upper half or the upper quarter. The presumption here is that if these employers can pay a higher wage and still prosper, that the others can do so as well, and that an increase in the wages paid by the latter will either force them to be more efficient, or if this is not done, to give way to the more effective employers who are more entitled to survive.

There is much weight in these contentions; but two objections need to be noted. (a) It is urged that the employees in the lower-wage establishments will tend to be less efficient than those in the better-paying plants, and hence it is improper to reason as though they were already producing what the latter are receiving. (b) It is urged that the employers who pay low wages are by nature also less efficient than those who pay the higher scale, and that to force up these wages will in effect drive them out of business, since they do not possess the ability to reduce costs in other ways. 
Fundamentally, this is a contention that there are not enough able managers to supply the needs of industry, and that the wage standards which the efficient voluntarily assume should not be imposed on the less able.

2. A second test is, obviously, that of the degree to which the industry is able to earn interest on capital and profits. If the general average of profits in an industry is comparatively high in terms of the amounts invested while wages are comparatively below the general average, then the case for increasing the wage level is strong.

If an industry earns only a low rate of interest, and if numerous firms are close to bankruptcy, then obviously an increase in wages should be approached with great caution. If the wages are at least equal to what similar labor receives elsewhere, then it is probably wise not to disturb the situation. If wages are, however, also comparatively low, the question of an increase will hinge upon three considerations: (a) The degree to which there are latent improvements in technique and management which could increase output per man hour, and hence help to counterbalance in whole or in part an increase in wage rates. (b) The degree to which an increase in wages could be passed on to the consumers in the form of an increase in prices and in gross receipts. For where both labor and capital are underpaid in comparison with what is received elsewhere, it would seem as though either the industry is inefficient or the consumers are profiting unduly from low prices, and are therefore parasitic to this degree upon those who furnish them with these commodities. (c) The degree to which it may be possible and wise to transfer labor and capital from the industry in question to other industries.

3. The question whether an increase in wages can be compensated for by an increase in prices is obviously of great importance, and needs to be examined in more detail. There is evidence to indicate that general wage increases in Australia tend to be followed fairly speedily by increases in the scale of tariff duties, in order to prevent foreign competitors from making inroads upon the market. It is also quite possible that there may be a gentleman's understanding among the employers that such increases are also to be followed by a compensating advance in the internal level of prices. This, if fully carried out, may leave the parties in much the same relative position as before..$^{35}$

There is strong evidence to indicate that this is precisely what happened in this country under the N.R.A. Wages were increased, but the employers-through their code authorities and their price and production controls, were able in the main at least to protect their relative position.

35 If interest and profits are increased commensurately with wages. 
So far as industry as a whole is concerned, a general advance in prices would also be conditioned upon whether or not the banking system would increase its volume of loans. If it did so in proportion to the increase in unit costs, then perhaps the same volume of total output could be maintained as would otherwise be the case, but at a higher price level. There would be a distinct question, however, whether the general position of labor would be appreciably improved, or whether the gains in money wages would not be counterbalanced by the increase in the cost of living.

If the amount of credit or monetary purchasing power were not expanded in proportion to the increase in price per unit, the inevitable result would seem to be a decrease in the quantity of goods demanded, and hence in the numbers employed. Unemployment would, under these conditions, increase.

If the increases in wages were not to be general, but were confined to a specific industry or to a few industries, then the effect of an increase in price would hinge upon the relative elasticity of demand for the commodities in question. If the demand were inelastic, i.e., if an increase in price of I per cent were accompanied by a decrease in the quantity demanded of less than I per cent, then such an increase in unit price would be accompanied by some increase in total receipts, and the condition of the laborers who remained within the industry could be improved, and possibly the position of capital as well. ${ }^{36}$ If the demand were elastic, however, and the increase in wages and prices were accompanied by a more than proportionate reduction in the quantities of the articles purchased, then the burden of unemployment would tend to be heavy and the position of the owners weakened.

\section{VII}

Let us now consider the fundamental case against wage fixation by the government. This is fundamentally based upon the contentions: (I) That the workers now tend to receive approximately what the last worker or group of workers adds to the social product. This is what is known as the law of marginal productivity. (2) That if the level of wages were pushed up above this point, then workers would be paid more than the last group had added. Employers would, therefore, lay off some of the workers, and would continue to reduce their force until the amount added by the last worker or group of workers was again equal to the higher wage. This would cause unemployment to increase. If there were free competi-

${ }^{36}$ But purchasing power would be withdrawn from other industries, and the problems of these groups made more difficult. 
tion between laborers and a fluid wage system, these men would then offer to work for less than the raised wage, since otherwise they would earn nothing; and the pressure of this competition would ultimately bring wages back to the original point where the quantity of labor demanded would be equal to the quantity of labor supplied. But if an inflexibility of wages is prescribed by government mandate, then the higher wage can only be maintained by keeping a proportion of the workers unemployed, and by diminishing the national income in the process.

This theory rests indeed upon two pillars. The first is the principle that if one factor of production, such as labor, is increased while the other factors are held constant that while the total product will increase, it will do so at less than the proportionate rate by which the variable factor has increased. In consequence, the total product curve will increase by diminishing increments, and if these increments, or the curve of first differences, are plotted on a graph with the quantity of the factor as $x$, or the independent variable, they will have a negative slope. This is known as the law of diminishing marginal (i.e., incremental) productivity. ${ }^{37}$ The second pillar of the theory is the belief in a state of perfect competition, or in something approaching it, under which employers compete for labor and workers for jobs, where both labor and capital are mobile, and where there is little or no unemployment of either labor or capital except where it is caused by a rate of return higher than the marginal product of the last unit of the total supply. Let us discuss each of these basic arguments in turn.

If all of the factors of production were to increase simultaneously and at the same rate, the most plausible assumption to make is that product itself would increase at that rate. That is, a doubling in the quantity of labor, of capital, and of natural resources with technology unaltered can be expected to produce a doubling in product. If the quantity of labor is, however, doubled while the quantities of capital and natural resources are unaltered, the increase in the total product will be less than roo per cent. This of necessity must be so to the degree that natural resources and capital make some contribution to the total product, since a doubling upon their part in conjunction with labor is required to double the total product. Total product will, therefore, increase relatively more slowly than the proportionate increase in the quantity of labor alone. This will

${ }^{37}$ See Von Thunen, Der Isolierte Staat (Zweiter Teil) 557-84 (r930); Clark, The Distribution of Wealth (1899); Wickstead, An Essay on the Coordination of the Theories of Production and Distribution (1894); Walras, Elements d'économie politique pure, Barone, Studi sulla distribuzione, I2 Giornale degli Economisti I07-55; 235-53 (1896). 
be according to some such curve on a logarithmic scale as that shown in Chart r. $^{37 a}$

\section{CHART 1}

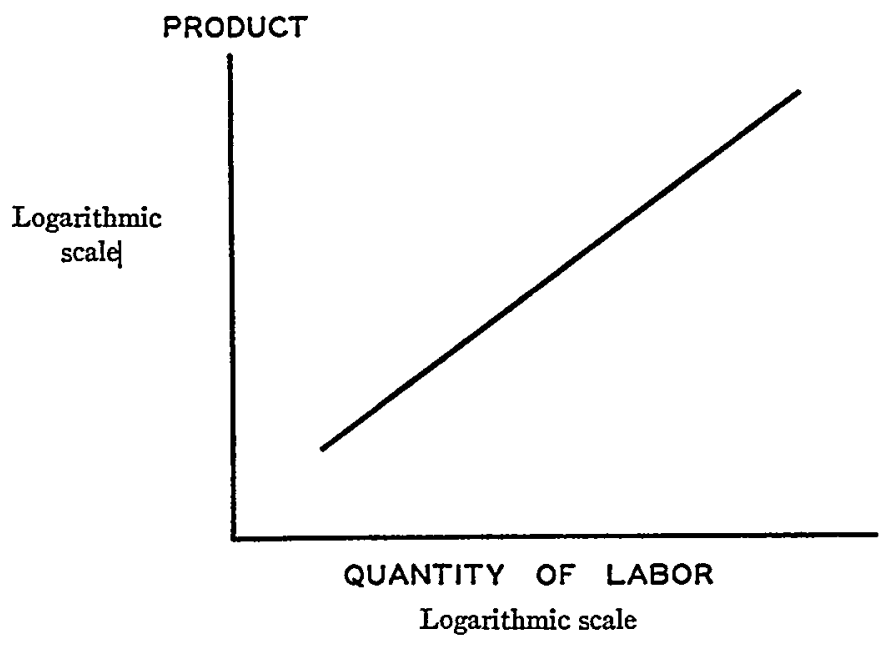

Here, a doubling in the quantity of labor causes product to increase by 75 per cent.

TABLE 2

An Iriustration of the Efrect upon Total and Incremental, Production OF INCREASING THE QUANTITY OF LABOR IN RELATION to THE QUANTITY of Capital aNd Natural Resources

\begin{tabular}{|c|c|c|c|c|c|}
\hline \multicolumn{2}{|c|}{ QUANIITY OF FACTORS } & \multirow{2}{*}{$\begin{array}{l}\text { PERCENTAGE } \\
\text { INCREASE IN } \\
\text { LABOR AS COY- } \\
\text { PARED WITH } \\
\text { PREVIOUS } \\
\text { QUANTITY } \\
\text { (3) }\end{array}$} & \multirow{2}{*}{$\begin{array}{c}\text { Percentage } \\
\text { INCREASe IN } \\
\text { Product (75 } \\
\text { PER Cent of } \\
\text { Proportionate } \\
\text { INCREASE } \\
\text { IN LABOR) } \\
(4)\end{array}$} & \multirow{2}{*}{$\begin{array}{c}\text { AMOUNT OF INCREASE IN } \\
\text { ProDUCT (COI. } 4 \text { APPLIED } \\
\text { TO PRECEDING ITEMS IN } \\
\text { Cor. 6) }\end{array}$} & \multirow{2}{*}{$\begin{array}{c}\text { Total } \\
\text { Product } \\
\text { Precedng } \\
\text { Product PLus } \\
\text { Ircresomat } \\
\text { of Col. } 5 \\
(6)\end{array}$} \\
\hline $\begin{array}{l}\text { Labor } \\
\text { (I) }\end{array}$ & $\begin{array}{c}\text { Natural } \\
\text { Resources } \\
\text { and Capital } \\
\text { (2) }\end{array}$ & & & & \\
\hline $\begin{array}{l}1 \\
2 \\
3 \\
4 \\
5 \\
6 \\
7\end{array}$ & $\begin{array}{l}\mathbf{I} \\
\mathbf{I} \\
\mathbf{I} \\
\mathbf{I} \\
\mathbf{I} \\
\mathbf{I} \\
\mathbf{I}\end{array}$ & $\begin{array}{c}\cdots \cdots \\
100 \\
50 \\
33^{\frac{1}{3}} \\
25 \\
20 \\
16 \frac{2}{3}\end{array}$ & $\begin{array}{l}\cdots \cdots \cdots \\
75 \\
37.50 \\
25 \\
18.75 \\
15 \\
12.50\end{array}$ & $\begin{array}{l}(1.0 \times \times 75)=.75 \\
(1.75 \times .375)=.6563 \\
(2.4063 \times .25)=.6016 \\
(3.0079 X .1875)=.5626 \\
(3.5705 X .15)=.5356 \\
(4.1061 X .125)=.5232\end{array}$ & $\begin{array}{l}1.0 \\
x .75 \\
2.4063 \\
3.0079 \\
3.5705 \\
4.1061 \\
4.6293\end{array}$ \\
\hline
\end{tabular}

Such a curve of total product carries with it the principle that the increment by which the total product grows, decreases with each unit

37a This line is fitted to the function $\log y=a+.75 \log x$ where $a$ has a positive value. It would perhaps be clearer were $a$ omitted so that $\log y=.75 \log x$. 
addition of labor. A simple arithmetical illustration will make this clear. The key to it is the fact that the percentage increase in production is only three-fourths of the percentage increase in the number of laborers.

It will be seen from this (i.e., by column 5) that the absolute amounts of the increments to the total product caused by the addition of another worker, diminish as successive workers are added. These are shown separately in Chart 2, and illustrate the principle of diminishing incremental or marginal productivity.

\section{CHART 2}

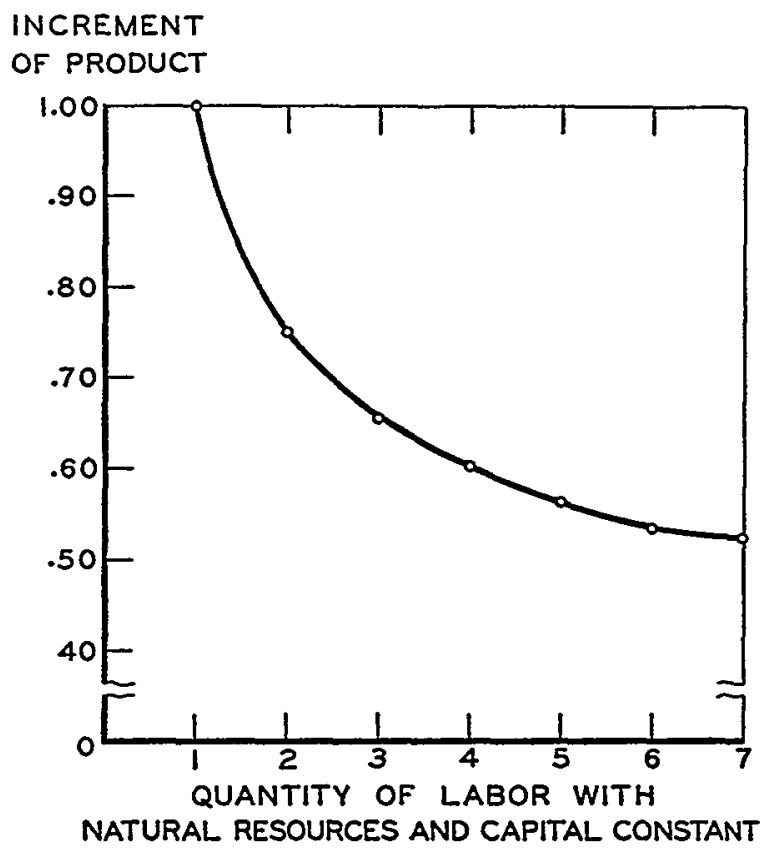

If there is perfect competition for laborers and for jobs, the amount added by the last worker will tend to be the wage paid to each. ${ }^{38}$ For if the wage is less than this amount, then the quantity of labor demanded by employers will be more than that supplied, since employers will profit from hiring workers whose wages will be less than what they add to the product. But if more workers are demanded than can be supplied, the inevitable result under competitive conditions is to cause employers to compete against each other for labor by raising the wage. This process will go on until the wage is raised to the point where the quantity of labor de-

${ }^{38}$ In this, we assume a homogeneity between the different units of labor. 
manded is equal to that supplied. This is equal to the amount added to the product by the last worker or group of workers, and is the point at which the market is cleared.

Conversely, if wages are raised above this point, the employers will demand fewer workers, since they will not want to pay more to workers than they add to the product. This, as has been stated, will create unemployment. If governmental or trade-union regulations are not imposed, then these unemployed will be able to find jobs by offering to work for less; and this process will go on until wages are once again reduced to the point of marginal productivity. If this lowering of wages is made impossible by governmental action through the fixing of a minimum, then the

TABLE 3

Approxtmate Valdes Found for Manufacturing of Effect OF INCREASES IN THE QUANTITIES OF LABOR AND CAPITAL RESPECTIVEIY

\begin{tabular}{|c|c|c|c|}
\hline \multirow[t]{2}{*}{ Countray } & \multirow[t]{2}{*}{ Period } & \multicolumn{2}{|c|}{$\begin{array}{l}\text { Percentage Increase in } \\
\text { Manufacturing Prodoct } \\
\text { With Increase of I Per } \\
\text { Cent IN Given Factor AloNe }\end{array}$} \\
\hline & & Labor & Capital \\
\hline $\begin{array}{l}\text { United States........ } \\
\text { Massachusetts....... } \\
\text { New South Wales.... } \\
\text { Victoria............ }\end{array}$ & $\begin{array}{l}1899-1922 \\
\text { I80-I926 } \\
\text { Ig0I-I927 } \\
\text { I907-I929 }\end{array}$ & $\begin{array}{l}.75 \\
.74 \\
.65 \\
.71\end{array}$ & $\begin{array}{l}.25 \\
.26 \\
.35 \\
.29\end{array}$ \\
\hline
\end{tabular}

result will be that a permanent group of unemployed is created-unless by the growth of capital and the improvement of technology, marginal productivity for the labor supply as a whole is raised to the level of the new wage.

The next issue which presents itself is that of the slope or elasticity of this curve of diminishing marginal productivity, which under perfect competition we may identify as the ultimate demand curve for labor. From studies which several of us have made concerning the relations between historical changes in the quantities of labor, capital, and product, in manufacturing for the United States, Massachusetts, New South Wales and Victoria, the "normal" effect of (a) an increase of I per cent in the quantity of labor with capital constant, and (b) an increase of I per cent in the quantity of capital with labor constant, has been as shown in Table 3.39

39 For the statistical and mathematical evidence upon which the results are based, see P. H. Douglas, op. cit, supra note I2, Ir3-202; P. H. Douglas and Handsaker, op. cit., supra note I2. 
It will be noticed that there is a substantial degree of uniformity between the results. The fact that the New South Wales results are the farthest away from the others is partially due to the nature of the index of capital, which is computed on a somewhat different basis from that followed in other studies.

Now, it can be demonstrated that: (I) The flexibility of the marginal productivity curve of a factor, i.e., the rate at which the marginal productivity of factor changes with a percentage change in its quantity, is equal to the sum of the exponents of the other factors. When we deal with only two factors, this means that the flexibility of the marginal productivity curve for labor is represented by the exponent for capital and vice versa. This means that an increase of I per cent in the quantity of labor will normally cause, so far as manufacturing is concerned, and if other things are constant, a decrease of from $\frac{1}{3}$ to $\frac{1}{4}$ of I per cent in the marginal productivity of labor. (2) The elasticity of the marginal productivity curve is the reciprocal of its flexibility. This represents the relative percentage change in the quantity of a factor which is required (if other things are equal) to effect a change of I per cent in the marginal productivity of that factor. For labor, it would-according to the studies mentioned-apparently be between -3.0 and -4.0 .

I have stated elsewhere ${ }^{4^{0}}$ the consequences of all this under the assumptions of a competitive economy. "The fact that the elasticity of the demand for labor seems to be between -3.0 and -4.0 , indicates that where unemployment is caused by a wage rate which is higher than marginal productivity, a reduction of one per cent in the rate of wages should normally lead to an increase of 3 or 4 per cent in the volume of employment and hence to an increase in the total income of the workers of from 2 to 3 per cent. If wages are pushed up above the point of marginal productivity, the decrease in employment would normally be from three to four times as great as the increase in hourly rates so that the total income of the working class would be reduced in the ratio indicated above. It should also be noted that Pigou in his recent Theory of Unemployment arrives by almost purely deductive methods at an almost identical estimate of the elasticity of demand for labor during periods of depression, namely, that it is "probably not less than - 3.0." "

I hastened to add, however, that it did "not follow however that the cause of unemployment is uniformly a wage which is in excess of marginal productivity. There are other causes of a seasonal, cyclical, and tech-

${ }^{40}$ The Theory of Wages 5or (I934). 
nological nature and in these cases a reduction in the wage rate need not invariably bring the greater expansion in employment."

The opponents of wage regulation (of which I am not one if it is properly conducted) take such studies as these to support their contentions that the fixation of wages should be left to the adjustment of "economic law," and that the government should keep its hands off lest, in so doing, it raise wages above the level of social marginal productivity and (a) create a larger percentage of unemployment than that by which it raises the wages of those who continue to be employed, (b) consequently diminish the total amount to be paid to labor as a whole, as well as decrease the total national income at the same time.

\section{VIII}

The foregoing objections have, however, been based on the assumption of perfect competition in the selling of goods and the buying of labor To the degree that this competition is imperfect and monopoly conditions are instead at least partially present, the conclusions which have just been drawn must be distinctly modified. Let us take up first the modifications introduced by imperfect competition in the production and sale of commodities. ${ }^{4}$

The theory of perfect competition is based upon the assumption that the number of individual producers is so infinite that alterations in the output of any one establishment will have no effect upon the price per unit. Thus, if a Kansas wheat grower produces 20,000 bushels instead of I0,000, the addition of 10,000 bushels is so infinitesimal that the world or even the national price of wheat would be unaltered. Price, under these conditions, is made for the individual establishment, and not $b y$ it. Total revenue increases at the same rate as output, and marginal (or incremental) revenue per unit of output will be the same as average revenue or price. The demand curve for an individual enterprise will be represented graphically by a horizontal line parallel to the base, and possessing infinite elasticity.

Under these productions, the individual firm will carry production to the point where the added (marginal) cost of the last unit will be equal to the average revenue or price at which all units will be sold. This, as stated, will also be equal to the marginal revenue. These conditions are illustrated in Chart 3. In the long run, as Viner has shown, ${ }^{42}$ a second con-

${ }^{41}$ See Robinson, The Economics of Imperfect Competition (1933); Chamberlin, The Theory of Monopolistic Competition (1933); Robinson, The Theory of Employment (r937).

${ }^{22}$ Viner, Cost Curves and Supply Curves, 3 Zeitschrift für Nationalökonomie $23-46$ (r93 I). 
dition will also determine output, namely, that average total unit cost, including interest on fixed investment, etc., will also equal unit price or average revenue.

Under imperfect competition, however, the output of an individual establishment does form such an appreciable fraction of the total supply that an increase in it is a distinctly noticeable addition to the total quantity sold. This will cause unit price or average revenue to fall. But-and this is the nub of the argument-this fall in price (or average revenue) will cause the increments of total revenue (or marginal revenue) to fall by a more rapid rate. For the fall in unit price consequent upon an in-

CHART 3

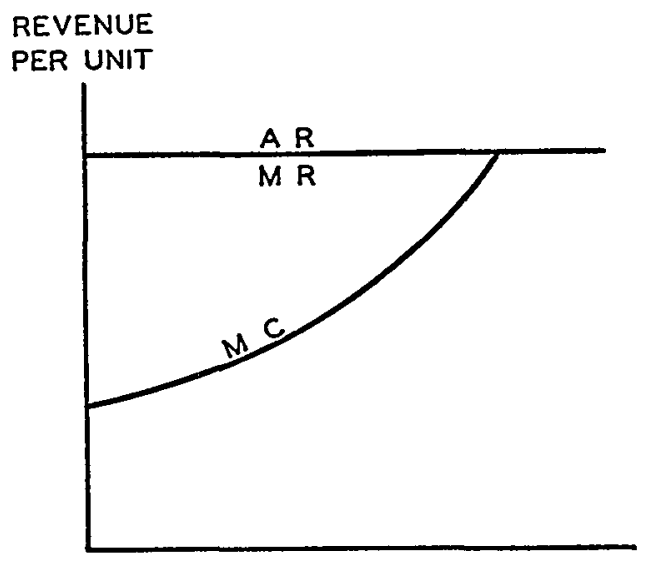

UNITS OF PRODUCT

crease in output causes the price of all of the preceding units, and not merely of the added units, to fall. This can be made clear by another numerical illustration, in which it is assumed that the elasticity of the price curve for an individual establishment is -4.0 , i.e., an increase of I per cent in its output causes price to fall by $\frac{1}{4}$ of $x$ per cent. Then if a firm produces roo units which sell for $\$ 100$ each, its total revenue will be $\$$ Io,000. If it expands its output to Ior, then the unit price-under the assumption made above-will fall to $\$ 99.75$, the total revenue will then be $\$$ ro,074.75 (i.e., $\$ 99.75 \times$ IOI). The addition to total revenue (or marginal revenue) will be $\$ 74.75$, which is $\$ 25$ less than the average revenue or price of $\$ 99.75$. If output is increased by a further unit to IO2, then unit price will fall virtually by another 25 cents to $\$ 99.5 \circ$, but total revenue will rise only to $\$$ Io, I 49 (i.e., $\$ 99.50 \times$ IO2). The addition to total revenue will be $\$ 74.25$ (i.e., \$IO,I $49-\$$ I0,074.75), or as unit price or 
average revenue falls by 25 cents, marginal revenue falls by 50 cents, or twice as much. The marginal revenue curve is, therefore, below the average curve, and this is illustrated in Chart 4.

Under these conditions production will not be carried to the point where marginal cost equals average revenue but to where it equals marginal revenue, since firms will not want to produce beyond the point where added income and outlay balance. For if they did so, then they

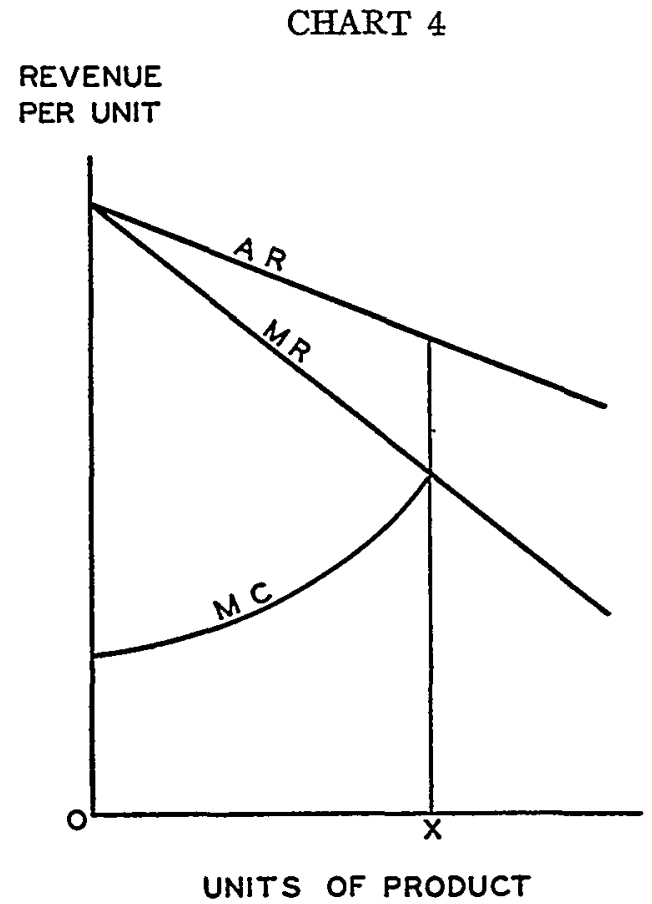

would be diminishing their net profits. The managers of business will make as profits upon the last unit produced and upon all others the difference between marginal revenue and average revenue, and these will constitute monopoly gains. This also is shown in Chart 4.

Labor will receive as a producers wage the amount the last worker adds to the product, or marginal physical product multiplied by the marginal revenue (MR). But as consumers, they will pay for the goods average revenue (AR). Hence they will suffer an exploitation of the difference between $A R$ and $M R$.

It is urged that under such circumstances, unionism and governmental wage fixation can reduce the amount of exploitation which results from 
imperfect competition, and that the case for governmental action is established.

The opponent of governmental wage regulation, even while admitting the reality of imperfect competition in certain lines, will, however, interpose three objections to this conclusion.

(I) If labor is exploited by the difference between marginal revenue and price, capital is equally exploited, since the same principle applies there as well, and therefore it is said that labor is not discriminated against. This defense, however, overlooks the fact that the enterprisers who are presumed to pocket the difference between average revenue and marginal revenue are themselves the stockholders or/and the managers. These groups are not distinct from the capitalist class, but are instead a part of it. While it may be true that the class of rentiers may, because of such forces, receive less than would otherwise be the case, the more active capitalists will receive not only this residue, but also the deductions from the true marginal productivity of labor.

(2) It will also be contended that while it is possible to have imperfect competition in a few industries nevertheless when this becomes more universalized, forces are set in motion which make the continuance of any such condition virtually impossible. Under imperfect competition, as we have seen, production within an enterprise, will be carried to the point where marginal costs are equal to marginal revenue, not to where they equal average revenue. Since the marginal cost curve is a rising one, this means that equilibrium for the enterprise will be reached earlier and at a lower output than under perfect competition. But this means, in turn, that less labor and capital will be used than would otherwise be. This labor and capital will be squeezed into other fields, but as these are also brought into a more imperfect state of competition, the no man's land in which they may find refuge shrinks more and more. Either they must stay in these overcrowded fields where they have to content themselves with a far lower marginal return than prevails elsewhere, or they will combine and try to break into the imperfectly competitive fields and largely help to restore competition there. In this latter case, they will greatly reduce, and perhaps eliminate, the monopoly gains which were formerly obtained from an exploitation of the factors of production.

In appraising this contention, it may be granted that there will be some such tendency; but that it can go far enough to establish a state of perfect competition seems impossible. For in order to do so, the size of the productive units would have to decrease so that each enterprise would produce only an infinitesimal fraction of the output of a given industry. Any 
such development is highly unlikely; and as long as the output of given firms does comprise an appreciable portion of total supply, there will be a discrepancy between marginal and average revenue and to the degree that this exists there will be an "exploitation" of labor.

(3) The third defense is that even if imperfect competition continues, an increase in wages will restrict production and cause unemployment just as much as it would under perfect competition. An increase in wages, unless accompanied by an increase in efficiency, would mean increasing the cost of producing successive units, and hence would raise the whole marginal cost curve. This will mean that the marginal cost curve will cut the marginal revenue curve (MR) at a higher point where the total output will necessarily be smaller than it was before the wage increase was granted. This smaller output will mean less employment, and consequently a displacement of labor. It is, therefore, urged that whatever may be the evils of imperfect competition and quasi-monopoly, an increase in wages is not the way to cure them or to restore balance.

This is an important point. But while it is true that some unemployment would be caused by such an increase in wages, it would not be as great as it would be under conditions of perfect competition. For since the marginal revenue curve is negatively inclined, an upward shifting of the cost curve would cause the new intersection to differ from the former by less than would be the case were it and the average revenue curve to be identical and horizontal to the base, as they would be under conditions of perfect competition. Whether under these circumstances the increase in money wages per worker who continued to be employed would form a larger aggregate than the amount lost through unemployment, would depend largely upon the relative elasticity of the marginal revenue curve. The steeper its slope, and consequently the less elastic it is, the greater the possibility for an increase in total money wages. But in this connection it should also be remembered that the prices of the commodities will themselves be higher and hence will help to offset any such money gain as may develop.

As we have previously stated, the principles of marginal productivity may be violated not only by monopolies or quasi-monopolies in the selling of goods, but also by similar forces in the buying of labor. Thus, there are many towns and smaller cities in the country which are each more or less dependent upon one plant for employment. Under these conditions, the employer will not need to offer the full marginal productivity in order to attract labor. The one protection which labor will have in the absence of unionization or government action will be to go to other towns or cities 
if the wage falls too low. But this is an imperfect balancing force, since: (a) Working-class families do not like to pull up home ties; and it is still true as Adam Smith observed one hundred and sixty years ago, that "man is of all baggage, the most difficult to be transported." (b) The immediate alternative which is frequently open is merely to go to another company dominated town, where wages are once more fixed more or less monopolistically at less than the marginal product. In these cases, the worker who migrates changes monopolists, but does not get into a truly competitive market.

In larger cities, where there are numerous employers, there are frequently understandings, and in some cases more or less formal compacts between them, fixing basic maximum wage rates for unskilled labor and for other types, and which are accompanied by implicit or explicit pledges not to pay more than this. Under these circumstances, therefore, wages can continue under the point of true marginal production because there is not the competition between employers which is depended upon in the competitive economy to bring wages up to marginal productivity, should they at any time fall below that point. There is some evidence, as unearthed by the Senate Sub-Committee on Civil Liberties that many of the giant companies in the country talk over wage policies with each other; and there is at least the possibility that they may take joint and cooperative action in fixing basic scales.

\section{IX}

It is not easy to pass a matured and comprehensive judgment upon all of the tangled issues involved in the question of wage regulation. From the considerations which have been brought forward, the following tentative conclusions may perhaps be justified.

I. There is sufficient evidence that competition fails to work perfectly, and that there is a considerable degree of monopoly or imperfect competition in the purchase of labor, as to make one skeptical about wages being fixed solely by natural law. To the degree that these non-competitive forces are at work, there is a strong case for governmental participation in the fixing of at least some wage rates.

2. There is need also for the fixation of minima in certain specific industries where-due to severe competitive pressure-the employers are able to drive the wage scale down to grossly inadequate levels because the working force lacks sufficient mobility to transfer itself to other regions and industries. This was the case in industries which were formerly manned almost exclusively by recent immigrants; and it is still true of 
certain industries where the workers are primarily negroes, immigrants, or native whites in small towns or cities, who are not able to seek work elsewhere. Exploitation may well exist in those cases, and the consumers may not be meeting the human costs of production. The fixation of a minimum would fix a bottom below which the pressure of competition could not force the workers.

3. There are no economic reasons, as distinguished from political and constitutional considerations, why wage regulation should be confined to women. There are instead sound reasons for including men as well.

4. There would, however, be great dangers in the fixation by the government of wage rates in all or in most industries. For if large increases were generally granted by the government, then if these were increases in real wages and not merely in money rates, this might well raise wages above the amounts added by the last units of labor, and hence cause industry to lay off large numbers of men, and at once decrease the real national income and increase the burden of unemployment.

5. The governmental fixation of wage rates should, therefore, primarily be confined to industries where the basic rate for unskilled labor is appreciably below the general average for the section as a whole. Here it is proper to raise the minimum by fixing an initial floor for wages which will be based upon what the employers in the upper half or quarter pay for such labor under competitive conditions. Even if the median wage or the arithmetic average is used as the new minimum in such cases, much good can be done. Where there is strong evidence to indicate that wages are forced down by direct monopoly pressure below what they would be under conditions of competition, the standard should be what similar workers obtain in centers which are not too far distant, and where there is genuine competitive bidding for labor.

6. The cost of living for a family of five should not be used as the standard in fixing the wages for men, since only a small percentage of the workers have four such dependents, while the great majority have fewer than this number.

7. The groups which need aid most are the large-sized families which have a considerable number of children to support. These are now the worst sufferers. It is impracticable at present to fix a basic wage which will be sufficient for them, since this would mean granting large and relatively less needed surpluses to the single men and those without dependent children, or with only one such child. But children s allowances could be paid to those with dependent children in such a fashion as not to make it more difficult for them to find employment. This could be done 
in two ways. (a) By creating a system of industrial or geographical funds which would pay an allowance for each dependent child of an employed, worker, and which would raise the necessary funds by assessing employers a given per cent on their total payroll. In this way, an employer would have to pay the same assessment upon a bachelor with a given basic wage, as upon a man with ten dependent children, who for his services in the workshop received the same amount. But the children would be protected far more adequately than would otherwise be possible. This would be a means of making a given increase in the total wages bill do the greatest good.

(b) The second means would be for the government to pay out the children's allowances, but to raise the money as much as possible by assessing monopoly profits. In this way, the cost would be thrown primarily upon economic surpluses rather than upon margins. This is always better, since an increase of costs at the margin is always likely either to increase prices appreciably or to increase unemployment, or finally, to do both.

If there are those who fear that such a program would unduly stimulate the birth rate, these anxieties could perhaps be met by a provision that the allowances were not to be paid in behalf of more than three or four children in a given family.

While this suggestion for children's allowances may seem highly impracticable to many, it should be remembered that it is now the universal practice for employed workers in France and Belgium, and that it is also used in New South Wales, and for families of more than five in New Zealand. ${ }^{43}$

8. So great are the administrative and enforcing difficulties that the government should primarily confine itself to the fixation of basic wages in the substandard industries, and to the creation of a system of children's allowances, and should abstain from fixing differential rates for the more skilled workers. These should be adjusted either by individual or by collective bargaining between employer and employee. For the more that that can be done by voluntary bodies, the less is the burden heaped upon the government.

9. Due caution should be exercised not to disrupt unduly the industry

${ }_{43}$ See Douglas, Wages and the Family (1925); Rathbone, The Disinherited Family (r924); Rathbone, The Ethics and Economics of Family Endowment (I927); Vibart, Family Allowances in Practice (1924); Cohen, Family Income Insurance (r926); Family Allowances, The International Labour Office (I926); Family Allowances in Foreign Countries, U.S. Bureau of Labor Statistics, Bull. 4 or (I926); Fallon, Les Allocations familiales en Belgique et en France (I926). 
of a large section of the country. The low wages of the south are partially due to a lack of free competition between the purchasers of labor power, but they are also partially due to the low marginal productivity of labor in southern agriculture. This latter tendency is, in turn, caused by a high degree of population pressure upon soils which are frequently relatively depleted, and by many social and political forces as well. The low return in southern agriculture makes it possible for southern industry to draw workers away from the farms by a wage which would not attract labor in the north. Fundamentally the problem here is whether manufacturing industry shall be drawn to areas where the marginal productivity in agriculture is low or whether laborers shall be drawn from these areas to others where the marginal productivity is high. While there are undoubted evils to correct, the problem should nevertheless be approached with caution.

Io. The employers should not be given the virtual power to fix prices in return for wage fixation, as was the practice in the N.R.A., and which is now being followed in the case of coal, and which is also proposed for textiles. While the relative immobility of labor and capital in the coal mining industry may justify some special treatment, this privilege should not be widely extended. For if it were, we would be likely to find that the employers would gain back appreciably more in the form of higher prices than they had granted in the form of higher wages so that the actual distribution of income might be made even more unequal. The problem of business depressions would also be made more severe, since the area of frozen prices would be increased and the area of free prices reduced.

II. Any wage structure set up should be made as flexible as possible. In periods of rising prices and increasing per capita output, wages should be advanced so that the owners of industry will not profit unduly at the expense of the workers. In periods of falling prices due to decreases in the quantities of active bank credit, the maintenance of rigid wages will tend to grind the owners of industry between the upper and nether millstones by greatly reducing or abolishing profits, and hence lead to a curtailment of production and employment. A decrease in wages in these cases would permit costs to fall and production to be maintained.

Similarly, in the case of monopolies the rigid maintenance of both prices and wages in the face of a generally falling price level would choke off the demand for these goods and hence create unemployment. In many cases it would also withdraw purchasing power from the competitive industries, and thus make their problems even more difficult. There is need for flexibility here as well, but this should apply to prices as well as to wages. The workers should not be expected to practice flexibility alone. 
It is not pretended that these tentative suggestions constitute a full answer to all of the economic problems involved in the governmental regulation of wages. Even within the field covered, they are not expressed in any dogmatic spirit, while there are obviously many issues which they do not cover, such as $(x)$ the problem of regulating the length of the normal working week, overtime, etc.; (2) the problem of learners, apprentices, etc.; (3) the question of whether differentials should be provided between the sexes and if so, according to what standards; (4) the question of permits to work at lower than the fixed minima for aged and substandard workers, etc.; (5) the administrative problems of procedure and of the determination of wages; (6) the respective roles of the federal and state governments; (7) the problem of enforcement, etc.

If, however, this article has served to indicate some of the fundamental economic issues which are involved, and if it stimulates discussion upon a somewhat deeper level of thought than has hitherto characterized the handling of this issue it will have fulfilled its purpose. 